\title{
SCZEPNOŚĆ MIECDZYWARSTWOWA W NOWOBUDOWANYCH NAWIERZCHNIACH W POLSCE
}

\begin{abstract}
W artykule przedstawiono analizę wyników badań sczepności międzywarstwowej warstw asfaltowych przeprowadzonych na podstawie danych $\mathrm{z}$ monitoringu właściwości fizyko-mechanicznych warstw asfaltowych z lat 2012-2013. Monitoring prowadziły Laboratoria Drogowe oddziałów GDDKiA w ramach własnych badań kontrolnych podczas realizowanych inwestycji. Analizie poddano 7043 wyników badań sczepności międzywarstwowej badanych próbek, odwierconych z nawierzchni budowanych autostrad, dróg ekspresowych i głównych krajowych oraz towarzyszących dróg wojewódzkich i powiatowych na różnych etapach budowy. W większości przypadków były to nawierzchnie nie oddane do ruchu. Przedstawiono analizy wybranych statystyk sczepności dla wszystkich połączeń warstw asfaltowych oraz analizy wpływu wymiarów uziarnienia stykających się warstw, jak i wpływu temperatury otoczenia na sczepność międzywarstwową. Stwierdzono, że największy problem sczepności występuje pomiędzy warstwami podbudowapodbudowa i wiążąca-podbudowa. Na niewłaściwe połączenie istotnie wpływa brak gradacji uziarnienia stykających się warstw asfaltowych, powodując zanik efektu zazębienia, jak i zaniżone temperatury otoczenia podczas wbudowywania warstw. Przedstawione wyniki badań są częścią programu badawczego realizowanego przez Katedrę Inżynierii Drogowej Politechniki Gdańskiej na zlecenie Generalnej Dyrekcji Dróg Krajowych i Autostrad.
\end{abstract}

Słowa kluczowe: wytrzymałość na ścinanie, mechanizm sklejenia i zazębienia, uziarnienie mieszanek mineralno-asfaltowych, siła połączenia warstw

\section{Wstęp}

\subsection{Wprowadzenie}

$\mathrm{Na}$ świecie i w Polsce w projektowaniu konstrukcji nawierzchni zakłada się, a podczas wykonawstwa konstrukcji nawierzchni oczekuje i wymaga się pełnego połączenia poszczególnych warstw konstrukcji nawierzchni, a w szczególności warstw asfaltowych [1]-[3], [4], [5]. Zwyczajową praktyką dla osiągnięcia połączenia oraz stworzenia bariery przeciwwodnej jest wykonanie warstwy sczepnej,

\footnotetext{
${ }^{1}$ Piotr Jaskuła, Politechnika Gdańska, Narutowicza 11, 80-233 Gdańsk, pjask@pg.gda.pl
} 
skropienia międzywarstwowego z emulsji asfaltowej pomiędzy kolejnymi warstwami konstrukcji nawierzchni. Polskie specyfikacje techniczne od początku ich istnienia podają ilościowe zakresy skropienia w zależności od rodzaju stykających się warstw. Zalecane wartości skropienia wynikają z doświadczenia, obserwacji dobrego zachowania się nawierzchni, a nie są wynikiem analiz mechanicznych właściwości sczepności międzywarstwowej. W okresie ostatnich 10 lat istotnie zmieniły się przepisy techniczne, dotyczące projektowania i produkcji mieszanek mineralno-asfaltowych oraz materiałów stosowanych w technologiach asfaltowych. Pojawiły się problemy z uzyskaniem sczepności międzywarstwowej pomiędzy poszczególnymi warstwami asfaltowymi, a w specyfikacjach technicznych, jak i projektach wykonawczych poza ilością skropienia brakuje wyraźnych wskazówek do zmaksymalizowania wytrzymałości na ścinanie połączenia.

\subsection{Badania sczepności międzywarstwowej warstw asfaltowych}

Analizę wyników badań sczepności międzywarstwowej warstw asfaltowych przeprowadzono na podstawie danych z monitoringu właściwości fizykomechanicznych warstw asfaltowych prowadzonego w latach 2012-2013 przez Laboratoria Drogowe oddziałów GDDKiA w ramach własnych badań kontrolnych podczas prowadzonych inwestycji [6]. Analizie poddano 7043 wyników badań sczepności międzywarstwowej badanych na próbek o średnicy 100 i $150 \mathrm{~mm}$, odwierconych z nawierzchni budowanych autostrad, dróg ekspresowych i głównych krajowych oraz towarzyszących dróg wojewódzkich i powiatowych na różnych etapach budowy. Próbki do badań sczepności międzywarstwowej pochodziły z 74 odcinków nowobudowanych lub remontowanych dróg. W przypadku 512 prób z 7043 wyników badania sczepności dysponowano jednocześnie wynikami oznaczenia właściwości fizycznych badanych mieszanek mineralnoasfaltowych tj. wielkości uziarnienia, zawartości asfaltu, zawartości wolnych przestrzeni oraz wskaźnika zagęszczenia. Wybrane dane wykorzystano w analizach poszukiwania korelacji pomiędzy sczepnością międzywarstwową i parametrami fizycznymi stykających się warstw z mieszanek mineralno-asfaltowych.

Badania sczepności międzywarstwowej wykonywano w temperaturze $+20^{\circ} \mathrm{C}$, przy wykorzystaniu prasy Marshalla i aparatu Leutnera. Prędkość przemieszczania się tłoka prasy podczas ścinania wynosiła $50 \mathrm{~mm} / \mathrm{min}$.

\section{Analiza wyników badań sczepności międzywarstwowej}

\subsection{Zestawienie ogólne}

Zestawienie wszystkich wyników badań sczepności międzywarstwowej $\mathrm{z}$ podziałem na poszczególne połączenia warstw przedstawiono $\mathrm{w}$ tablicy 1 .

Zestawienie wyników monitoringu sczepności międzywarstwowej pokazuje, że mimo problemów z połączeniem międzywarstwowym podczas realizacji inwestycji można osiągnąć satysfakcjonujące wyniki, co widać po dużych śred- 
Tablica 1. Zestawienie wyników badań sczepności międzywarstwowej wykonanych metodą Leutnera, w temperaturze $+20^{\circ} \mathrm{C}$

Table 1 . Summary of the interlayer bonding results from the Leutner test, carried out at $+20^{\circ} \mathrm{C}$

\begin{tabular}{|c|l|c|c|c|}
\hline \multirow{2}{*}{ Lp. } & Parametr statystyczny & \multicolumn{3}{|c|}{ Wyniki połączeń międzywarstwowych warstw: } \\
\cline { 3 - 5 } & $\begin{array}{c}\text { ścieralna-wiążąca } \\
\text { (ś-w) }\end{array}$ & $\begin{array}{c}\text { wiąca- } \\
\text { podbudowa } \\
\text { (w-p) }\end{array}$ & $\begin{array}{c}\text { podbudowa górna- } \\
\text { dolna } \\
\text { (pg-pd) }\end{array}$ \\
\hline 1. & Liczba próbek & 1966 & 2386 & 2490 \\
\hline 2. & $\begin{array}{l}\text { Średnia wytrzymałość na } \\
\text { ścinanie [MPa] }\end{array}$ & 1,64 & 1,53 & 1,56 \\
\hline 3. & $\begin{array}{l}\text { Odchylenie standardowe } \\
\text { [MPa] }\end{array}$ & 0,52 & 0,82 & 0,91 \\
\hline 4. & Wskaźnik zmienności & $31 \%$ & $54 \%$ & $58 \%$ \\
\hline 5. & Mediana [MPa] & 1,7 & 1,5 & 1,6 \\
\hline 6. & Wartość min. >0 [MPa] & 0,2 & 0,1 & 0,1 \\
\hline 7. & Wartość max. [MPa] & 4,2 & 5,2 & 7,9 \\
\hline 8. & $\begin{array}{l}\text { Liczba próbek; stwierdzono } \\
\text { brak sczepności (rozpad } \\
\text { warstw podczas odwiertu) }\end{array}$ & 21 & 173 & 165 \\
\hline 9. & $\begin{array}{l}\text { Liczba próbek; stwierdzono } \\
\text { wartości mniejsze od kryte- } \\
\text { rium tymczasowego }\end{array}$ & 147 & 360 & 443 \\
\hline
\end{tabular}

nich wartościach wytrzymałości na ścinanie dla poszczególnych połączeń warstw: ścieralna-wiążąca - 1,6 MPa, wiążąca-podbudowa - 1,5 MPa i podbudowa górna-podbudowa dolna - 1,6 MPa. Można zaobserwować, że wskaźnik zmienności wyników sczepności jest mniejszy dla warstw ścieralna-wiążąca i wynosi $31 \%$ podczas, gdy dla warstw wiążaca-podbudowa i podbudowa górnapodbudowa dolna wynosi odpowiednio $54 \%$ i $58 \%$. Wpływa to na ilość prób, które nie spełniają tymczasowego kryterium sczepności dla warstw ś-w 147 prób z 1966, w-p 360 prób z 2386 i pg-pd 443 prób z 2490. W sumie nie spełniło kryterium 13,9\% wszystkich badanych próbek. Najmniej próbek przypadków nie spełniło kryterium połączenie warstw ścieralna-wiążąca 7,5\%, najwięcej przypadków niespełnienia kryterium połączenia warstw podbudowa górnapodbudowa dolna $17,8 \%$. W połączeniu wiążąca-podbudowa odnotowano $15,1 \%$ próbek nie spełniających kryterium (patrz rys. 1A).

Na rys.1B przedstawiono proporcje liczby próbek nie spełniających kryteriów, czyli dla warstw ś-w wytrzymałości na ścinanie mniejsze od $1 \mathrm{MPa}$, a w przypadku warstw w-p i p-p mniejsze od $0,7 \mathrm{MPa}$ oraz liczby próbek, w których stwierdzono brak sczepności międzywarstwowej - wytrzymałość na ścinanie równa $0 \mathrm{MPa}$. Wartość 0 oznacza, że próbki po lub w czasie pobierania rozpadły się. Widać, że problem całkowitego braku sczepności, gdzie wytrzymałość na ścinanie jest zerowa, jest marginalny w połączeniu warstw ścieralnawiążąca, czego nie można już powiedzieć o połączeniach warstw wiążącapodbudowa i podbudowa górna-podbudowa dolna. 


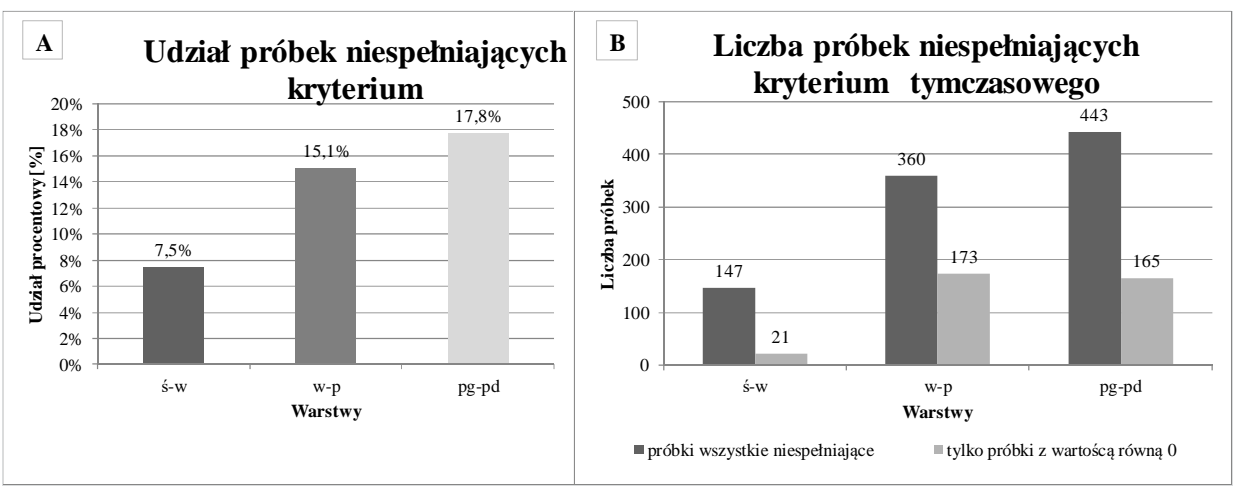

Rys. 1. A) Udział procentowy próbek niespełniających kryterium tymczasowego sczepności międzywarstwowej, B) Liczba próbek niespełniających kryterium tymczasowego sczepności międzywarstwowej

Fig. 1. A) The percentage of specimen which do not pass the temporary interlayer bonding criterion, B) The number of specimen which do not pass the temporary interlayer bonding criterion

\subsection{Wpływ uziarnienia mieszanek mineralno-asfaltowych}

Na rys. 2, 3 i 4 przedstawiono udział procentowy par poszczególnych rodzajów MMA (z uwzględnieniem ich uziarnienia), stykających się w połączeniach międzywarstwowych, niespełniających kryterium sczepności międzywarstwowej. Można zauważyć wyraźną tendencję braku sczepności międzywarstwowej w przypadku takiego samego uziarnienie mieszanek stykających się w połączeniu warstw wiążąca-podbudowa (rys. 3) i podbudowa górnapodbudowa dolna (rys. 4). Podobne spostrzeżenia obserwowali Sholar i inni [7], West i inni [8], Collop i inni [9]. Różnica w uziarnieniu warstw stykających się tzn. drobniejszej warstwy górnej, a grubszej warstwy dolnej, powoduje zmniejszenie udziału próbek niespełniających kryterium sczepności. Wynika to z możliwości lepszego klinowania się gorącej drobniejszej mieszanki w grubszej zimnej warstwie dolnej, co omówił dokładnie Glet [10] i Judycki [1], jak i podatności na dobre zagęszczenie [11], [12], [13].

W połączeniu warstw ścieralna-wiążąca nie ma już takiego trendu, jak w przypadku warstw niżej leżących (wiążąca-podbudowa, podbudowapodbudowa), gdyż zawsze występuje w tym przypadku różnica w uziarnieniu warstwy ścieralnej i wiążącej. Zaobserwować można za to prawidłowość lepszych sczepności w przypadku grubiej uziarnionych warstw ścieralnych, takich jak SMA12.8, SMA11 w stosunku do SMA8.

Stwierdzono istotny wpływ uziarnienia stykających się mieszanek mineralno-asfaltowych na sczepność międzywarstwową. W przypadku połączeń warstw niżej leżących tj. wiążąca-podbudowa, podbudowa-podbudowa należy bezwzględnie dążyć do różnicowania uziarnienia warstw stykających się oraz ograniczania stosowania warstw z kruszywem najgrubszym. Natomiast w przypadku połączeń warstw ścieralna-wiążąca problem braku sczepności jest marginalny, 
lecz zaobserwowano, że grubiej uziarnione SMA wykazuje mniejszy udział w braku połączenia międzywarstwowego.

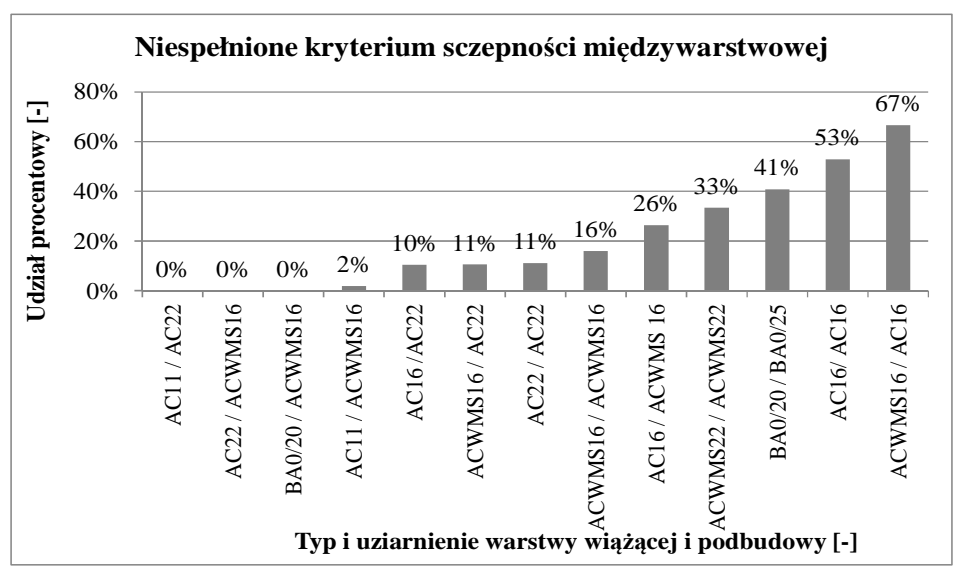

Rys. 2. Udział próbek niespełniających kryterium tymczasowego w zestawieniach mieszanek mineralno-asfaltowych przy połączeniu warstw wiążąca-podbudowa, 2318 próbek

Fig. 2. The percentage of specimen which do not pass the temporary interlayer bonding criterion, by the type of asphalt mixtures used in the connection binder course-base course, 2318 specimens

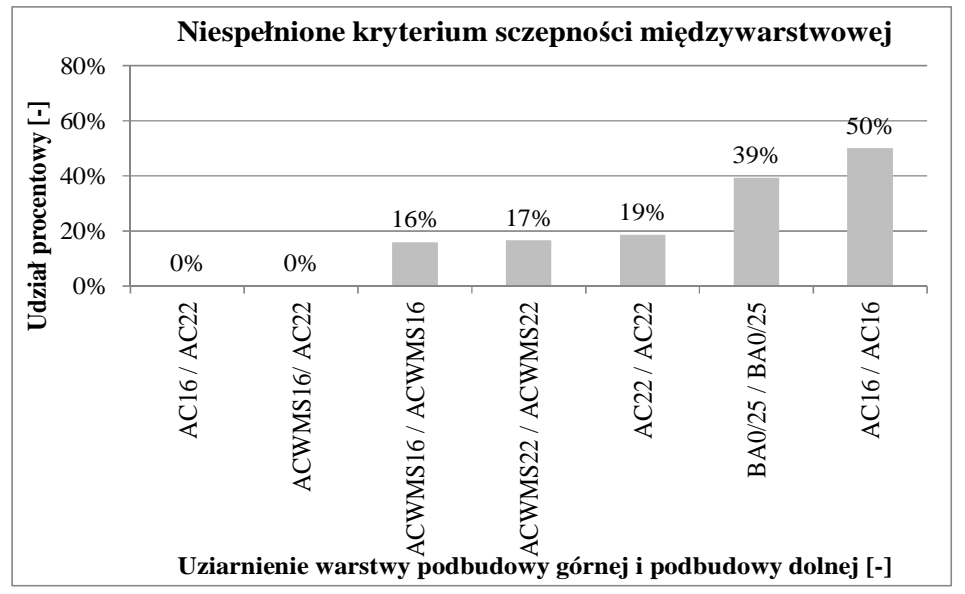

Rys. 3. Udział próbek niespełniających kryterium tymczasowego w zestawieniach mieszanek mineralno-asfaltowych przy połączeniu warstw podbudowa górna-podb. dolna, 2464 próbek

Fig. 3. The percentage of specimen which do not pass the temporary interlayer bonding criterion, by the type of asphalt mixtures used in the connection upper base course-lower base course, 2464 specimens 


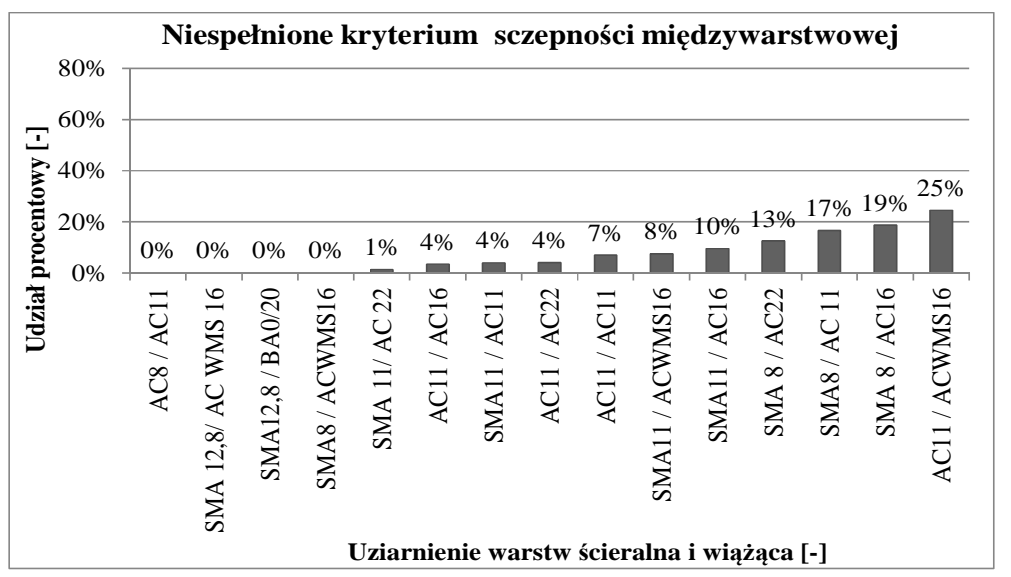

Rys. 4. Udział próbek niespełniających kryterium tymczasowego w zestawieniach mieszanek mineralno-asfaltowych przy połączeniu warstw ścieralnawiążąca, 1780 próbek

Fig. 4. The percentage of specimen which do not pass the temporary interlayer bonding criterion, by the type of asphalt mixtures used in the connection wearing course-binder course, 1780 specimens

\subsection{Wpływ temperatury powietrza na sczepność międzywarstwową}

Wpływ temperatury powietrza na sczepność międzywarstwową warstw asfaltowych oceniano na podstawie zestawienia udziału próbek niespełniających tymczasowych kryteriów sczepności i średniej temperatury powietrza w miesiącu wbudowania warstwy, uzyskanej ze stacji pogodowych.

Na rys. 5 zestawiono udziały próbek niespełniających tymczasowe kryteria sczepności w latach 2012 i 2013 tylko dla połączeń warstw wiążąca-podbudowa. Można stwierdzić, że istnieje obserwowalna zależność sczepności międzywarstwowej warstw wiążąca-podbudowa od temperatury powietrza (rys. 5). Podobne zależności zaobserwowano w przypadku oceny połączenia warstw podbudowy. Obniżone temperatury późno jesienne, zimowe i wiosenne powodowały zwiększony udział próbek o zmniejszonej lub zerowej sczepności międzywarstwową, co także obserwowano w pracy [1]. Nie zaobserwowano już jednoznacznych trendów przy ocenie połączenia warstw ścieralna-wiążąca.

\section{Wnioski}

Na podstawie przeprowadzonych analiz można stwierdzić, że mimo problemów z połączeniem międzywarstwowym podczas realizacji inwestycji można osiągnąć satysfakcjonujące wyniki, spełniające kryteria sczepności międzywarstwowej. Najmniejsze problemy zaobserwowano przy połączeniu warstw ścieralna-wiążąca, największe (dwukrotnie częstsze) obserwowano przy połączeniu warstw podbudowa górna-podbudowa dolna oraz wiążąca-podbudowa. 


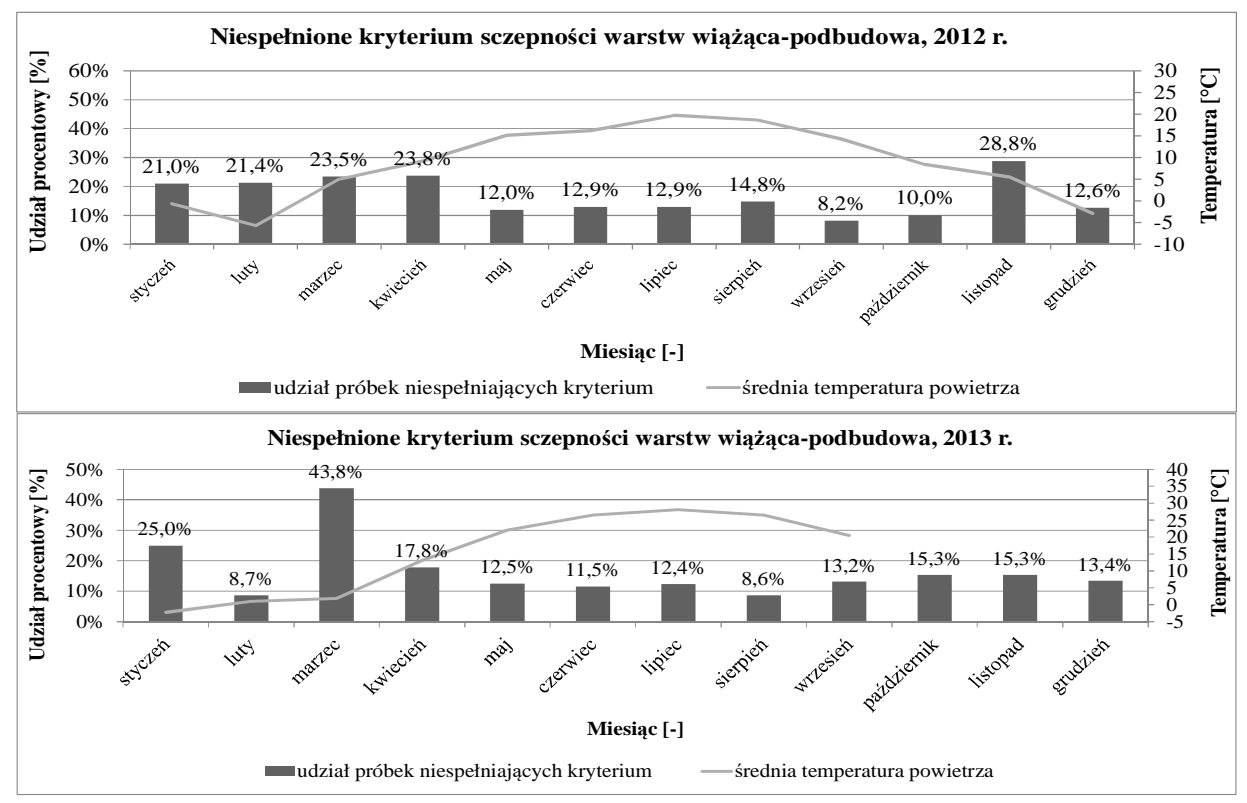

Rys. 5. Udział próbek niespełniających kryterium tymczasowego w zestawieniach mieszanek mineralno-asfaltowych przy połączeniu warstw wiążąca-podbudowa i temperatury powietrza

Fig. 5. The percentage of specimen which do not pass the temporary interlayer bonding criterion, connection between binder course-base course and the air temperature

Stwierdzono istotny wpływ uziarnienia stykających się mieszanek mineralno-asfaltowych na sczepność międzywarstwową. Należy bezwzględnie dążyć do różnicowania uziarnienia warstw stykających się oraz ograniczania stosowania warstw z kruszywem najgrubszym w przypadku podbudów i wiążących. W przypadku warstw ścieralnych zaobserwowano, że grubiej uziarnione SMA wykazuje rzadsze występowanie braku połączenia międzywarstwowego.

Istnieje obserwowalna zależność sczepności międzywarstwowej warstw wiążąca-podbudowa, podbudowa-podbudowa od temperatury powietrza. Obniżone temperatury późno jesienne, zimowe i wiosenne (a właściwie wydłużony czas rozpadu emulsji, zawilgocenie powietrza oraz większa prędkość wiatru) powodują zwiększony udział próbek z obniżoną lub zerową sczepnością międzywarstwową.

\section{Literatura}

[1] J. Judycki, "Sczepność między warstwami asfaltowymi nawierzchni," Drogownictwo, vol. 9, pp. 275-279, 2003.

[2] J. Judycki and P. Jaskuła, "Badania i ocena wpływu sczepności międzywarstwowej na trwałość konstrukcji nawierzchni asfaltowej, etap I,” Gdańsk, Poland, 2005.

[3] J. Judycki, P. Jaskuła, and A. Grądzka, "Modelowanie teoretyczne wpływu sczepności międzywarstwowej na zachowanie się nawierzchni asfaltowych, etap I," Gdańsk, Poland, 2011. 
[4] J. Uzan, M. Livneh, and Y. Eshed, "Investigation of adhesion properties between asphaltic-concrete layers," Aapt, vol. 47. pp. 495-521, 1978.

[5] J. Górszczyk and K. Malicki, "Trwałość zmęczeniowa połączeń warstw asfaltowych w badaniach laboratoryjnych," Zesz. Nauk. Politech. Rzesz, vol. 59, no. 283, pp. 199-206, 2012.

[6] J. Judycki and P. Jaskuła, "Modelowanie teoretyczne wpływu sczepności międzywarstwowej na zachowanie się nawierzchni asfaltowych, etap III," Gdańsk, Poland, 2013.

[7] G. A. Sholar, G. C. Page, J. A. Musselman, P. B. Upshaw, and H. L. Moseley, "Preliminary Investigation of a Test Method to Evaluate Bond Strength of Bituminous Tack Coats," Florida, 2002.

[8] R. C. West, J. Zhang, and J. Moore, "Evaluation of bond strength between pavement layers," no. December, p. 63, 2005.

[9] A. C. Collop, N. H. Thom, and C. Sangiorgi, "Assessment of bond condition using the Leutner shear test," Proc. Inst. Civ. Eng., pp. 211-217, 2003.

[10] W.K. Glet, opracowanie Wałecka H., "Układ i związanie warstw w konstrukcjach nawierzchni asfaltowych," Strasse und Autobahn, vol. 5, 1999.

[11] P. Jaskuła, "Badania i analizy sczepności międzywarstwowej w nawierzchniach asfaltowych," Bud. i Archit., vol. 13, no. 4, pp. 117-125, 2014.

[12] P. Jaskuła, "Influence of compaction effectiveness on interlayer bonding of asphalt layers," in The 9th International Conference "ENVIRONMENTAL ENGINEERING," 2014, no. May, p. 7.

[13] C. Raab and M. N. Partl, "Effect of tack coats on interlayer shear bond of pavements," 8th Conf. Asph. Pavements South. Africa, no. September, p. 9, 2004.

\title{
THE INTERLAYER BONDING IN NEWLY CONSTRUCTED PAVEMENTS IN POLAND
}

\begin{abstract}
S u m m a r y
The paper presents the analysis of the results of interlayer bonding test based on data obtained from monitoring of physical and mechanical properties of asphalt layers from the period of January 2012 August 2013. The results were obtained from monitoring tests conducted by Road Laboratories of the General Directorate for National Roads and Motorways during construction phase. Analysis was made on the basis of interlayer bonding tests of 7043 specimens, cored out from the pavement of constructed Motorways, Expressways, Main National Roads and accompanying provincial and county roads. Specimens were obtained during different phases of construction. In most cases the pavements were not open for service. The paper presents the analysis of the selected interlayer bonding statistics for all bonds between asphalt layers and impact of the air temperature and maximum particle size in asphalt layers on the interlayer bonding. It was stated that the biggest problem with bonding occurred between base course and base course as well as between binder course and base course. The lack of appropriate interlayer bonding resulted from the lack of gradation of maximum particle sizes in adjoined layers (absence of aggregate interlock effect) and too low values of air temperature during construction of asphalt layers. Presented results are part of the larger research conducted by Department of Highway Engineering of Gdansk University of Technology for General Directorate for National Roads and Motorways.
\end{abstract}

Keywords: shear strength, bonding and interlocking mechanism, gradation of asphalt mixture, interlayer bonding strength

Przestano do redakcji: 07.06.2016 r.

Przyjęto do druku: 30.06.2016 r.

DOI: $10.7862 / \mathrm{rb} .2016 .79$ 